\title{
THE EFFECTS OF USING ENGLISH LANGUAGE APPLICATIONS IN DIFFERENT BUSINESS
}

\section{Pathitta Akkarathanakul}

${ }^{1}$ Suan Sunandha Rajabhat University. Email: pathitta.ak@ssru.ac.th

\begin{abstract}
Technology and digitalization is viewed as an integral part of the today's business world which has revolutionized the business operations. Digitalization has also affected marketing plans usage of social media and different business application is rapidly increasing to connect customers and business organizations. The growing number of foreigners in Thailand which has given rise to use of English language. This study is purposed to examine that how marketing performance of business are affected by different applications characteristic and contacts. The moderation effect of use of English language is also checked in this study. The relationship between these variables is analyzed by gathering responses from 372 foreigner's through online survey. The structural equation modeling tool was selected to evaluate hypothetical relationship between these constructs. The results found that effective application characteristics and content of these applications enhance business marketing performance and confirmed significance relationship between direct relationship and raveled insignificant indirect relationship of use of English language between applications characteristics and marketing performance. This paper provides useful implications for both literature and practice. It offers informative insights to researchers to expand research work. This study can be utilized by marketers to develop effective marketing plans implementing English language applications.
\end{abstract}

Keywords:

Business applications, characteristics, content, use of English language, business marketing performance, social media, digitalization, marketing, Thailand.

Article Received: 18 October 2020, Revised: 3 November 2020, Accepted: 24 December 2020

\section{Introduction}

English is the language of all modern technologies and businesses all over the world. In the past, the business was just a matter of regional or locally dealt on, that's why not as much needed any other language to be spoken or understood(van der Worp, Cenoz, \& Gorter, 2018). But now, with changes in technology, every field of life is influenced a lot by the use of the English language (Pennycook, 2020). Now, most of the business meetings, conferences, dealings, presentations, and visits are made through the modern technology of the internet and mobile applications are a major source of satisfying this need of time(Chaffey, Hemphill, \& Edmundson-Bird, 2019). According to Alkamel and Chouthaiwale (2018), English is the language of modern tools and equipment helping humanity all over the world. There is a great difference in business dealing and managing all the activities with the help of the English language and also the innovations in the field of technology to cope with modern business strategies(V Butova, I Dubskikh, Kisel, \& G Chigintseva, 2019). The below enlists some significant outcomes of effective English language business applications;

\begin{tabular}{|l|l|}
\hline Benefits & Description \\
\hline On-the-go accessibility & $\begin{array}{l}\text { Mobile apps are great ways to exhibit to customers what } \\
\text { business truly represents rather than telling them. }\end{array}$ \\
\hline Better connectivity & $\begin{array}{l}\text { One of the major significant properties of the mobile app } \\
\text { is that customers can access information even while they } \\
\text { are on the go. }\end{array}$ \\
\hline & $\begin{array}{l}\text { The mobile app makes it easy for potential customers to } \\
\text { get in touch with company services at any time. }\end{array}$ \\
\hline
\end{tabular}




\section{Improved customer engagement With a mobile app, a customer can have access to the business at any time of the day.}

The overall process of social media (SM) and mobile application has been considerably gaining significant attention from the academic analysts and researchers since the past few decades (Wichadee \& Pattanapichet, 2018). However, it can be recognized that even now a marketing performance difference exists in a different type of business as the number of firms and organizations performing as successful operations (Hiranburana et al., 2017). Wongwuttiwat, Buraphadeja, and Tantontrakul (2020) suggested that to address this performance difference, the contingent factors influencing the overall marketing performance of different businesses need to be recognized and evaluated in detail. As the researches on English language applications are sparse as well as limited, hence the study effort needs to be conducted on the businesses of developing regions (Thongsri, Shen, \& Bao, 2019). Therefore, the present study is new and positive in understanding the exclusive role of application properties and contents with the English language in improving the existing business

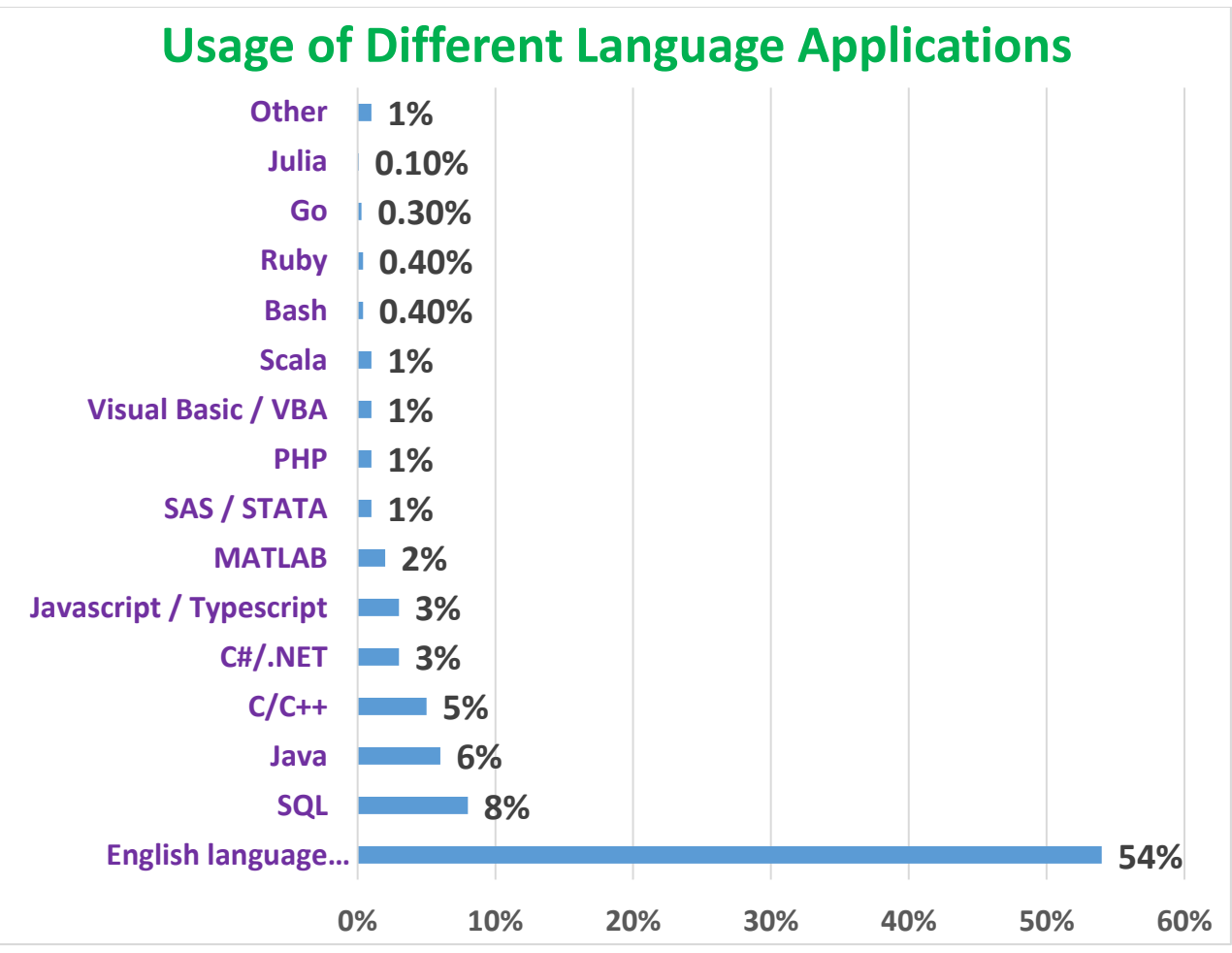

One of the major purposes of the following study is to provisionally investigate the effects of application characteristics (AC) and contents on the existing marketing performance of different firms and businesses in different settings. Besides, another major aim of the given research is to evaluate the moderating impact of English language use on the relationship between AC, ACon, and the business marketing presentation.

The results of the following study have two major significance and contributions to the existing literature, initial, this study majorly focused on provisionally evaluating the application elements like its characteristics and contents and according to Thongsri and Bao (2019), these elements are necessary for effective and favorable marketing popularity mainly in terms of significance and likes. Moreover, practically the findings of the present research are proving to be beneficial for academic analysts and scholars and the business policymakers who must promote a support framework for effective business applications. 
Further, this paper is organized into four sections including a review of the literature, research methodology, analysis and verdicts, and conclusion and discussion.

\section{Literature review}

\subsection{Stimulus-Organism-Response model}

(SOR)

The given model mainly serves as the analytical foundation that upholds the study model formulated in the present research. The given model was originally proposed by Robert S. Woodworth who was an American academic psychologist(C.-C. Chen \& Yao, 2018). Woodworth popularized and introduced the expression SOR to demonstrate his functionalist concept to psychology and to stress its gap from strictly SR concept of the behaviorists (Kim, Lee, \& Jung, 2020). According to Kamboj, Sarmah, Gupta, and Dwivedi (2018) within his modified SOR model, Woodworth recognized that the stimulus elicits a different effect and response depending on the condition of the organism (Bigne, Chatzipanagiotou, \& Ruiz, 2020). According to this model, the " $\mathrm{O}$ " for the organism mediates the association between the stimulus and the response (Zhao, Wang, \& Sun, 2020). Moreover, Woodworth also advocated the development of technical vocabulary for psychology rather than only depending on often subjective operational demonstrations.

The current research suggests that application elements like contents and characteristics be the stimuli to which the customers of different business acknowledge in mobile application facility. Customers' communications with these mobile app elements and parts will mainly act as an organism whereby the client's involvement in terms of comments and emotions are the response. According to Zhang, Pang, and Wan (2018), the given model was originally proposed in light of the business sector for the enhancement of businesses marketing performance.

\subsection{The relationship between application characteristics and business marketing performance}

The mass adoption and quick advancement of mobile applications have shifted how different businesses and customers interact and communicate (Hubert, Blut, Brock, Backhaus, \& Eberhardt, 2017). According to Ntarlas and Karayanni (2020), if a particular business does not offer a mobile application, in addition to a device friendly website, it will be critical for a business to engage customers and to surpass the competition. A business that lacks a successful and attractive application is lacking out on the chances to engage with customers and bring in innovative business (Lee, Ghasemkhani, Xie, \& Tan, 2019). With customers spending so many hours on their mobile devices, it is significant that a mobile application will boost value for the business performance, because according to Rajapathirana and Hui (2018), without an effective mobile presence, an organization may find it critical to succeed in marketing performance. Designing and characterizing a mobile application is very significant for the overall marketing performance of the business and it can take the business of the company to the next level (Yang \& Park, 2019). Furthermore, according to several analysts and scholars application characteristics mainly consists of two different types such as application vividness and application interactivity. According to $\mathrm{Yi}, \mathrm{He}$, and Yang (2019), vividness indicates the depth as well as the breadth of transmission content; the total resolution, as well as the quality of content appearance in the mobile application, is referred to as depth and the senses, sensory types, and cues listed in the marketing content are called as the breath which directly influence the interactivity level of the customer with the application, and which in turn improves the marketing performance of the business. Hence, in the line of the above discussion, the thesis suggested the below hypothesis; 
H1: Mobile application characteristics have a significant impact on business marketing performance.

\subsection{The correspondence between application contents and business marketing presentation}

In the modern use of technology, the business has become much easier and every step of dealing and managing business routine mobile applications are proving very helpful and beneficial to cope with all sorts of issues in business either of SME or the larger groups or companies all are using mobile applications(Verma, 2020). On the other hand, a business marketing presentation is also very important to represent the meetings, conferences, and also the presentation of the product by using mobile applications of English language contest. The available content in the English language helps a lot to understand the basics of matters relating to business. Today every individual is using mobile phone and internet services to access those sites which can help them to find out the information sufficient enough in finding the relevant data to solve the matter or issue within no time(Szymczak, 2018). The users of Google and other search engines feel at ease to find the solutions or summaries in seconds and this makes them attractive to use mobile application content and find out new and unique ideas, information, links, and also new varieties of presenting ideas and products in the markets efficiently. Thus there is a very positive and strong relationship between the application content and business marketing presentation very intelligently. Consequently, the given thesis hypothesized that:

H2: There is a significant linkage between application content and business marketing imaging.

\subsection{The mediating impact of English language use in the association between application characteristics and business marketing presentation}

According to Verma (2020), English has fast become the most widely used language in the world of trade, business, and marketing over the past few decades. As a result, having excellent content of English for business and marketing has become crucial for successes in any application future. English is widely used as a significant medium of communication for both small business purposes and large business entities alike which according to Malik, Merunka, Akram, Barnes, and Chen (2020) directly affect the characteristics of mobile applications positively. Moreover, English is the preferred language in the business community as several business partners and customers nowadays do not understand the same native language, so the English language increase the effectiveness level of application, and due to this the marketing performance of the business positively affected. Therefore, in the line of the above results, the study hypothesized that;

H3: English language use positively mediates the association between application properties and BMP.

\subsection{The mediating role of English language use in the interrelation between application contents and business marketing performance}

English as the language of more than half of the population of the world and understood well globally (Aydiner, Tatoglu, Bayraktar, Zaim, \& Delen, 2019; Owan \& Agunwa, 2019; Popoola, 2019; Puteri, 2018; Rahman \& Amir, 2019). This importance of the English language (EL) has created a huge impact and this has become the major language of the internet and IT. This language has not only covered education, research, and business but also has become the language of every modern technology and latest tools helping in business marketing performance. Application content within no time generates data that is available relating to asking questions and issues. Kale, Aknar, and Başar (2019) illustrate that the content available in the application is very informative and intellectual. The available data in the English language helps native and foreigners to find out their required material and then the material or data can be converted into the native language of the searcher. The EL is very helpful, 
informative, and also a huge bulk of vocabulary with different accents and usage helps a lot to make business presentations very informative, understandable, and providing the best presentation skills impresses the business community(Chuang \& Huang, 2018). Application content must have the quality to represent the information, knowledge, and intellectual ideas with variety and variations. English is used worldwide, so the material represented in the applications fulfills the demand of the customers and the need of the user and this presentation of reliable content make users use it on regular and continuous use. Thus application content has proved a helping source to promote business skills efficiently. Hence, based on the above presentation the study proposes that;

H4: English language use favorably mediates the relationship between application content and BMP.

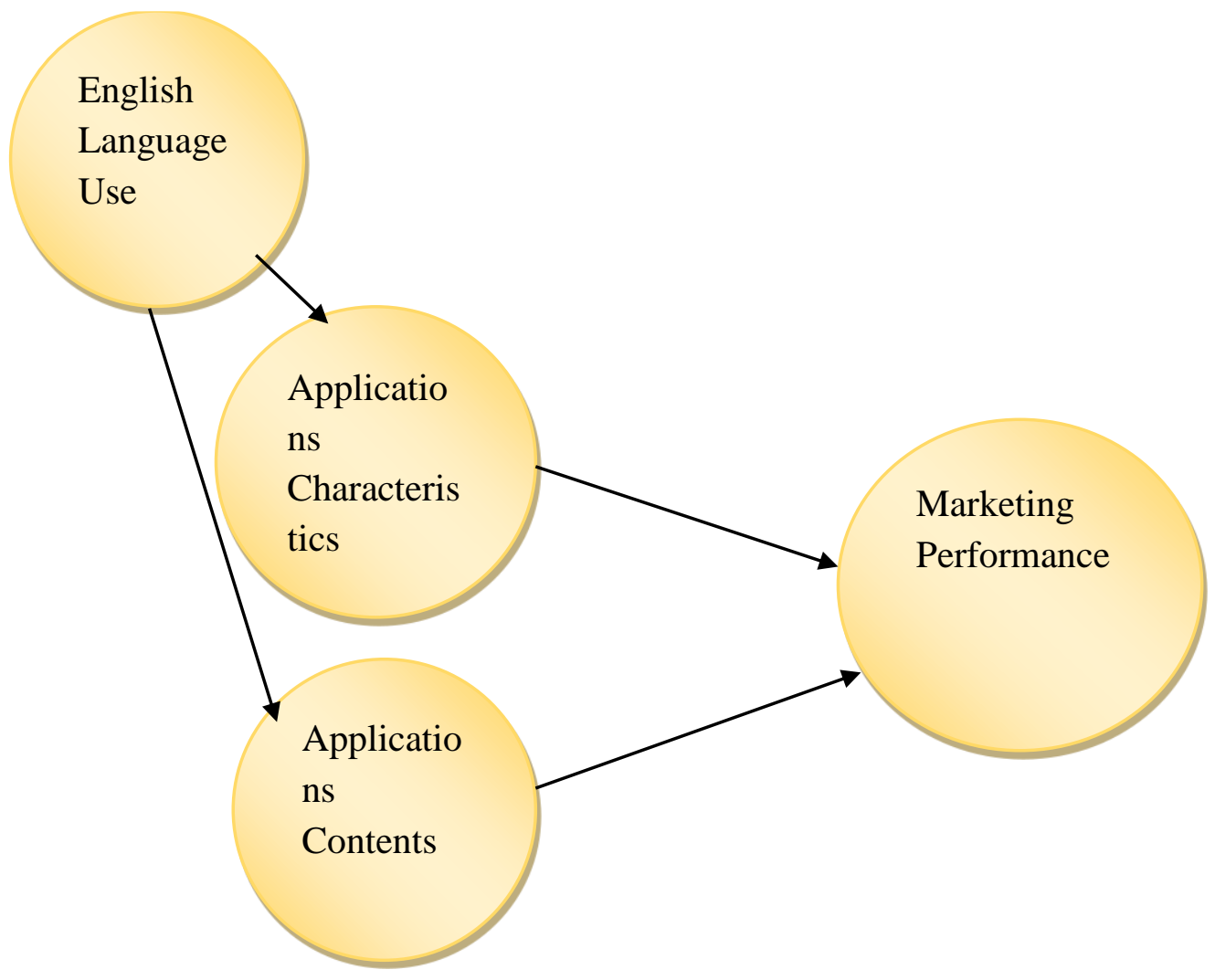

\section{Methodology}

\section{Sample and data}

This study was conducted in Thailand in view of emerging foreigners and international business, which has changed dynamics of interaction between businesses and customers due to crosscultural environment which necessitate use of English language. The population of this study was foreigners who are staying in Thailand. A sample of 372 foreigners was drawn from Bangkok via purposive sampling. Most of the respondents were staying in Thailand for jobs and business. To inspect the projected research model for present paper we used a questionnaire survey to obtain responses from large sample in less time. A self-reporting questionnaire was documented under supervision of English language experts and marketers to review wording of questionnaire. The survey was an online survey in which a structures questionnaire was distributed through WhatsApp among these respondents. The questionnaire was nationality based, if it was filled by a Thai it will automatically dropped from the sample. In final phase total 372 responses were considered usable collected during June and July 2020.

\section{Measurements}

The questionnaire had two sections, in $1^{\text {st }}$ section queries related to respondent's profile were stated 
to get demographic information. On other hand $2^{\text {nd }}$ section was made up of different items that were adopted from previous scales related to applications, use of English language and business marketing performance. A Five-point Likert type scale was implemented for quantifying responses. The application characteristics which has basically two dimensions (vividness and interactivity) was measured by instigating Coyle and Thorson (2001) scale. The scale has six-items, three were adopted for vividness and three evaluated interactivity Sample item is to estimate application characteristic is "How would you rank, if an application contains some images and pictures." respondents rated characteristics on five Point-Likert scale. From outcomes its composite reliability came 0.948 .

Seven items were develop to measure the application content in two dimensions (Information and entertainment) adapted from I.-J. Chen and Chang (2011). For example, "The contents of some applications are eye-catching and picks you up". Respondent were to rate it on 5-point response scale, results showing $\alpha=0.958$. For operationalization of use of English language, Ahn and Ferle (2008) study was exploited, three items were established to see the level of English language usage in business applications. One exemplary item is "How would you categorize yourself, you like reading in application in English?" responses presented on 5-point response scale showed $\alpha=0.924$.

For business marketing performance conceptualization study was used as a base to advance measures for business marketing performance, total 4 items are adjusted from this scale for example "our firm's sales reputation is good in in comparison to your main competitors" which was graded on 5 point Likert scale figuring out $\mathrm{CR}=0.912$.

\section{Data Analysis}

Statistical analysis for this paper was conducted on AMOS and SPSS to inspect the hypothesized relationship between variables. Confirmatory factor analysis and descriptive statistics test were also conducting using AMOS to test the reliability and validity of measurements. Cronbach's $\alpha$ and composite reliability (CR) were operated to check the reliability of the measurements that indicated good reliability.

\section{Result and Analysis.}

The present research was plotted in Thailand that targeted foreigners staying in Bangkok, however only 372 respondents were entitled for final sample. it was identified that in terms of gender majority of foreigners are male (205-55.21\%) and female were (167- 44.9\%). Age wise 121 foreigners $(32.5 \%)$ have age below 25 years Moreover, 146 foreigners (39.2\%) ages elasticities between 25 to 35 years, 90 foreigners (24.2\%) have its place to age group of 35 to 45 years and 15 respondents aged above 45 years $(4 \%)$. So Bangkok tends to have young foreigners staying working in Thailand. Out of 372 respondents 50 foreigners experience is $(13.4 \%$ - Less than 2 Years), 159 is $(42.7 \%-2$ to 5 Year $), 127$ foreigners $(34.1 \%-5$ to 8 Year) and 36 foreigners $(9.7 \%$ - More than 8 Year).

Table:2 Descriptive Statistics

\begin{tabular}{llllllll}
\hline & $\mathrm{N}$ & \multicolumn{3}{c}{ Minimum } & Maximum Mean & \multicolumn{3}{l}{ Std. Deviation Skewness } \\
\cline { 2 - 8 } & Statistic & Statistic & Statistic & Statistic & Statistic & Statistic & Std. Error \\
\hline AppliChan & 372 & 1.00 & 5.00 & 3.2935 & 1.02776 & -.237 & .126 \\
AppliCont & 372 & 1.00 & 5.00 & 3.4082 & 1.01378 & -.392 & .126 \\
EngLuse & 372 & 1.00 & 5.28 & 3.4784 & 1.10604 & -.556 & .126 \\
BMerkP & 372 & 1.00 & 5.00 & 3.5824 & 1.11750 & -.576 & .126 \\
Valid & $\mathrm{N} 372$ & & & & & & \\
(listwise) & & & & & & & \\
\hline
\end{tabular}




\section{Descriptive Statistics}

For summarizing the sample and data attributes and features Descriptive Statistics analysis was performed. Current $\mathrm{N}$ is 372 (no of observations) no outlier is encountered in variables except English langue use due to exceeding maximum value of 5 so use of English language has variance. The analysis conceded means for four constructs namely Application characteristics, applications content, English language use and business marketing performance as 3.2935, $3.4082,3.4784$ and 3.5824 in order. To test the normality of data skewness values are considered, here these values are in range of $-1+1$ confirming normal distribution.

Table:3 KMO and Bartlett's Test

\begin{tabular}{lll}
\hline Kaiser-Meyer-Olkin Measure of Sampling Adequacy. & .943 \\
Bartlett's Test of Sphericity & Approx. Chi-Square & 7300.995 \\
& df & 190 \\
& Sig. & .000 \\
\hline
\end{tabular}

KMO and Bartlett's Test is a statistical method to scrutinize the appropriateness of sample. The outcomes publicized .943 as Measure of Sampling which is nearer to 1 , besides this Bartlett's Test of Sphericity offers 7300.995as Approx. Chi-Square and 190 of degree of freedom with .000 level of significance which is a corroboration of sample adequacy rendering to the threshold range.

Rotated Component Matrix ${ }^{a}$

\begin{tabular}{|c|c|c|c|c|}
\hline & \multicolumn{4}{|c|}{ Component } \\
\hline & 1 & 2 & 3 & 4 \\
\hline CH1 & & .828 & & \\
\hline $\mathrm{CH} 2$ & & .860 & & \\
\hline $\mathrm{CH} 3$ & & .812 & & \\
\hline $\mathrm{CH} 4$ & & .807 & & \\
\hline CH5 & & .828 & & \\
\hline CH6 & & .849 & & \\
\hline $\mathrm{CO} 1$ & .850 & & & \\
\hline $\mathrm{CO} 2$ & .786 & & & \\
\hline $\mathrm{CO} 3$ & .757 & & & \\
\hline $\mathrm{CO} 4$ & .835 & & & \\
\hline CO5 & .828 & & & \\
\hline CO6 & .862 & & & \\
\hline $\mathrm{CO} 7$ & .852 & & & \\
\hline LU1 & & & & .856 \\
\hline LU2 & & & & .851 \\
\hline LU3 & & & & .840 \\
\hline MP1 & & & .771 & \\
\hline MP2 & & & .813 & \\
\hline MP3 & & & .858 & \\
\hline MP4 & & & .840 & \\
\hline
\end{tabular}

Rotated Component Matrix figures factor loading to measure the degree of correlation among variables and their items to see either the are consistent to each other or not. Total 20 items are advanced for four constructs and further evaluated by Confirmatory Factor Analysis. All items own 
factor loading above 0.7 and were acceptable such as application characteristic factor loading expanses from $\mathrm{CH} 1=.828$ and $\mathrm{CH} 6=.849$ which is clearing fulfilling the slandered of correlation and signpost that items did not come across any loading

error.

Table 5: Convergent and Discriminant Validity

\begin{tabular}{llllllll}
\hline & CR & AVE & MSV & CO & CH & LU & MP \\
\hline CO & 0.958 & 0.768 & 0.324 & $\mathbf{0 . 8 7 6}$ & & & \\
CH & 0.948 & 0.752 & 0.324 & 0.569 & $\mathbf{0 . 8 6 7}$ & & \\
LU & 0.924 & 0.803 & 0.316 & 0.562 & 0.529 & $\mathbf{0 . 8 9 6}$ & \\
MP & 0.912 & 0.722 & 0.318 & 0.564 & 0.506 & 0.498 & $\mathbf{0 . 8 4 9}$
\end{tabular}

Convergent Validity amount the degree to which variable are excepted to be consistent internally by computing $\mathrm{CR}$ and AVE on Confirmatory factor analysis. Findings put forward that application contents are most important factor as it gains uppermost composite reliability of 0.958 which. Marketing performance is least reliable in current variables as it has lowermost composite reliability 0.912 and correspondingly lowest AVE as 0.722 shown by the results so it has lowest reliability and variance. English language use is presenting highest $\mathrm{AVE}=0.803$. According to rule of thumb each variables CR and AVE must be (0.5 to 0.7), undoubtedly, is inferred that our findings are align with this range so convergent validity is proved. By the same token, Discriminant Validity of each variable is also totaled discretely and is delineated in diagonal order to evidently indicate the change between each variable (Albassami, Hameed, Naveed, \& Moshfegyan, 2019; Hameed, Basheer, Iqbal, Anwar, \& Ahmad, 2018; Rahmat, 2020; Ramli \& Maysari, 2020; Riyanti, 2018; Sayed \& Shusha, 2019; Seddighi \& Yoon, 2019; U1Hameed, Mohammad, \& Shahar, 2018).

Table 6: Model Fit Indices

\begin{tabular}{llllll}
\hline CFA Indicators & CMIN/DF & GFI & IFI & CFI & RMSEA \\
\hline Threshold Value & $\leq 3$ & $\geq 0.80$ & $\geq 0.90$ & $\geq 0.90$ & $\leq 0.08$ \\
Observed Value & 2.063 & 0.915 & 0.976 & 0.976 & 0.054 \\
\hline
\end{tabular}

Model Fit Indices is also based on confrimatory (0.915 - same or greater from .80), comparative factor analysis to qauntify the fitness to verify that model is approprtae for data. All constructed values are as conventional ranges, like discrepancy function CMIN/DF (2.063 - less fit index CFI and incremental fit index IFI (0.976 - greater than 0.90) and RMSEA (0.054- less than 0.8) which is a ultimately approval for than or equal to 3) goodness of fit index GFI model fitness.

Figure 3: CFA

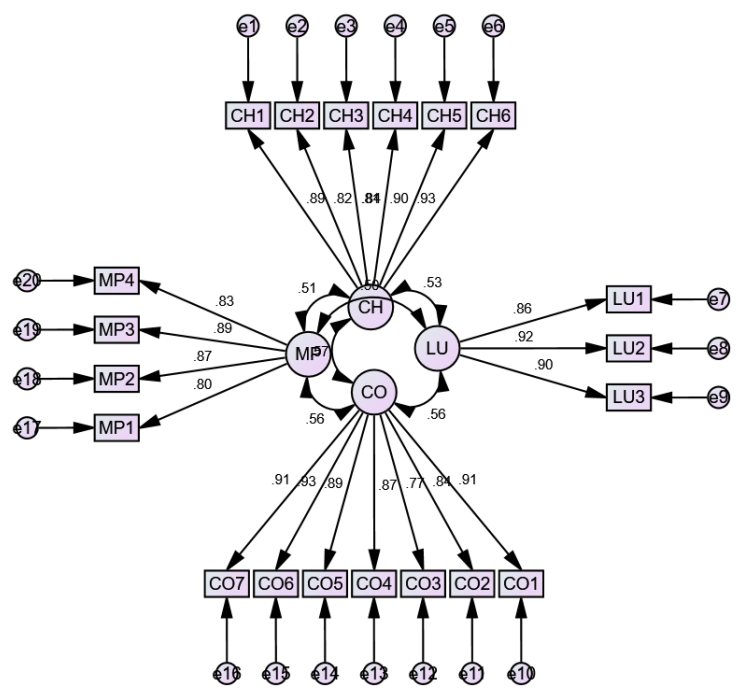


Table 7: Structural Equation Modeling

\begin{tabular}{lllllll}
\hline & & & Estimate & S.E. & C.R. & P \\
\hline BMerkP & $<---$ & AppliChan & .242 & .056 & 4.688 & $* * *$ \\
BMerkP & $<---$ & AppliCont & .398 & .057 & 7.702 & $* * *$ \\
& & & Estimate & S.E. & C.R. & P \\
ZBMerkP & $<---$ & CHxLU_Int1 & -.072 & .040 & -1.649 & .099 \\
ZBMerkP & $<---$ & CoxLU_Int2 & .177 & .035 & 4.072 & $* * *$ \\
\hline
\end{tabular}

Table no 6 is revealing the relationship between projected Four hypothesis by performing Structural Equation Model to get results to make the decision of accepting and rejecting hypothesis. It was learnt that application characteristics has direct positive relationship with business marketing performance as unitary adding in application characteristics derived marketing performance to be enhanced by $24.2 \%$ which eventually leads towards acceptance of proposed hypothesis (H1). The application content was found to be significantly related to business marketing performance as 1-unit increase in application contents stimulated marketing performance with $39.8 \%$ so it is validated $(\mathrm{H} 2)$. The moderating impact of use of English language on application characteristics and business marketing performance is insignificant (H3) due to its negative consequence as it lessens business marketing performance by $7.2 \%$, whereas English language use positively moderates applications content and, marketing performance by making an addition of $17.7 \%$. So in short all hypotheses are accepted expected $\mathrm{H} 3$.

\section{Figure 4: SEM}
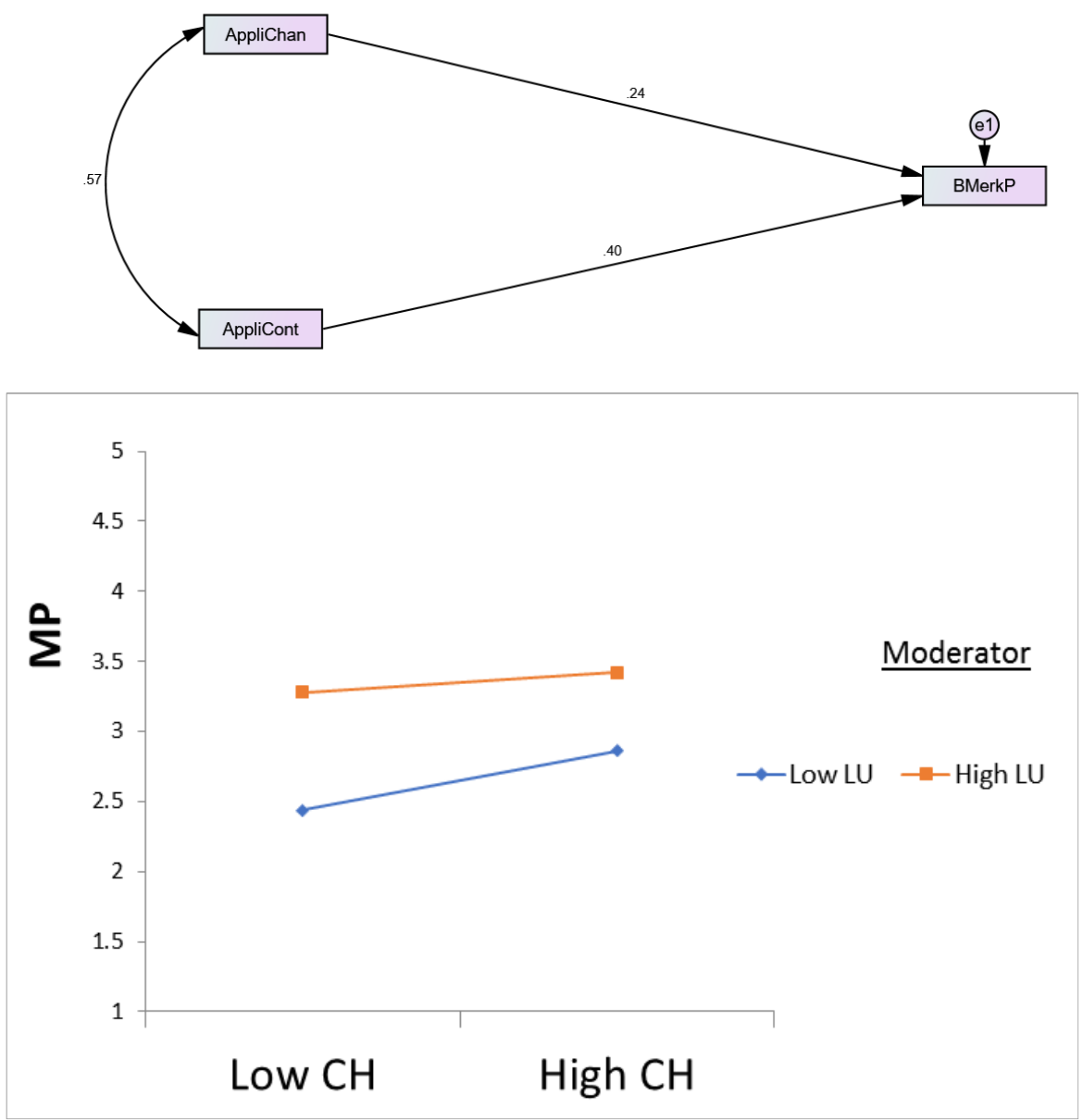


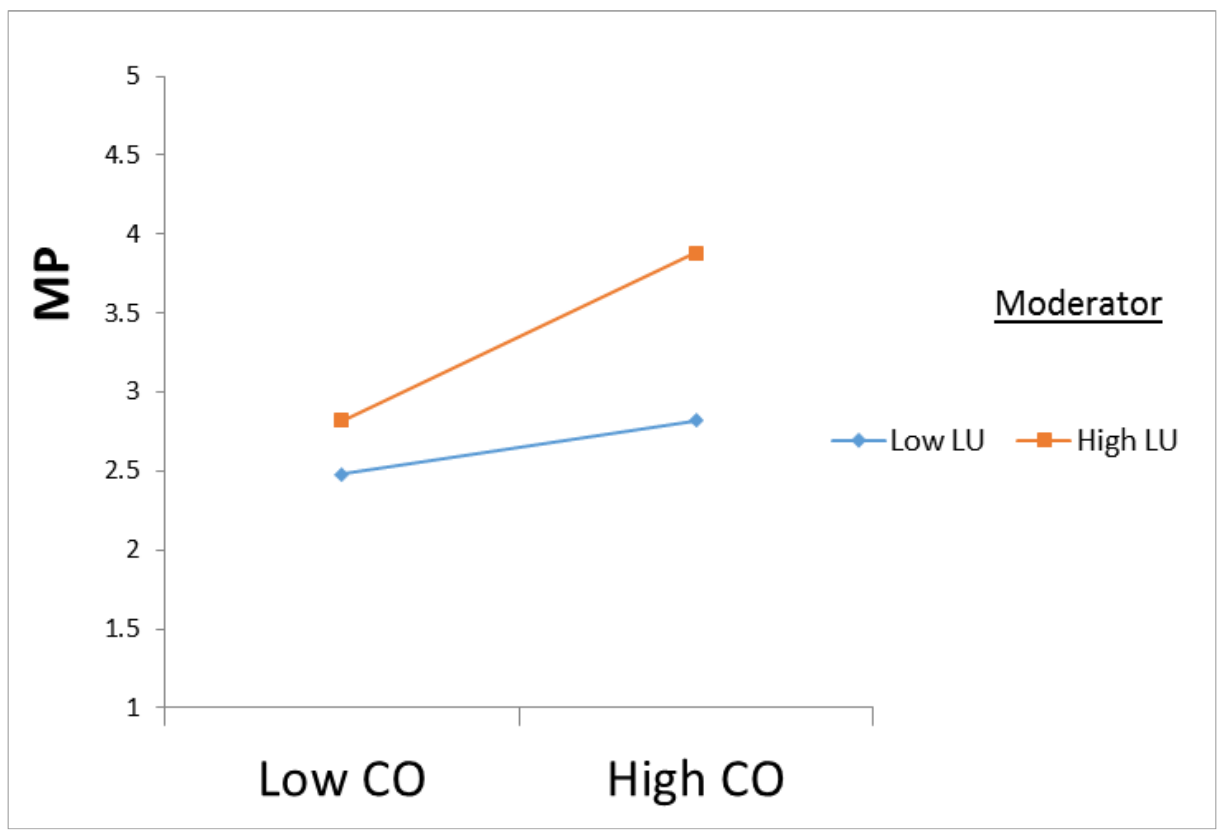

\section{Discussion and Conclusion}

In the view of increasing use of technology and cross-culture environment this study is conducted Thailand to see how marketing applications can influence marketing of a business along with moderation impact of English language use. To empirically examine how application characteristics and its content play its part in enhancing business marketing performance, and how use of English language strengthen this association for which current research model was dissected into four hypotheses for validation. H1 anticipated a significant and positive relationship between application characteristics and business marketing performance. According to results it turned out to be valid as marketing application possess effective characteristics if the application delivers a vivid and interactive communication than it will enhance the marketing performance of a business (Fortin \& Dholakia, 2005). Content of an application is also very important so $\mathrm{H} 2$ predicted a significant and direct relationship among business applicant content and business marketing performance. Results indicated that good content of applications significantly influence marketing performance, if an application provides valuable information desired by customers regarding the brand and the product it doubtlessly increases business marketing performance. Likewise, the application should be entertaining as well because entertaining applications arouse customers interest which leads to improved marketing performance as suggested by (Muntinga, Moorman, \& Smit, 2011). To see how use of English language moderate's applications characteristics and business marketing performance $\mathrm{h} 3$ was generated that expected a significant relationship between these variables. The results disclosed that use of English language has negative impact on applications characteristics and is confirmed to be insignificant. Use of English language also moderate application content and business marketing performance as $\mathrm{H} 4$ proposed, results supported this projection and highlighted that English language provide more useful information that foreigners can easily compute which subsequently lift business marketing performance (Nawaz et al., 2020).

So it can be concluded unquestionably that marketing applications play a key role in today technological drive business environment to sustain a business marketing performance, and using English language is crucial to maintain communication with foreigners and customers. This study emphasizes that applications vividness and two-way communication for interactivity is integral for marketing. This paper has many 
contributions, first of all it confirms significance of marketing application with previous studies. Future this paper adds up new findings in existing literature. It provides clear direction to advertisers and marketers to device marketing plans incorporating business applications. Considerably it suggests marketers and business management to use English language to attract more customers and enhance them involve. Applications developer can also be benefited from this study. This study is not free from limitations such as lower responses due to small sample, the quantitative method has restricted general application to other contexts. So it is suggested to adopt mixed method for study in future targeting more responses. The paper has only investigated this research model in marketing context in future it can cover other departments as well.

\section{REFERENCES}

[1] Ahn, J., \& Ferle, C. L. (2008). Enhancing recall and recognition for brand names and body copy: A mixed-language approach. Journal of Advertising, 37(3), 107-117.

[2] Albassami, A. M., Hameed, W. U., Naveed, R. T., \& Moshfegyan, M. (2019). Does Knowledge Management Expedite SMEs Performance through Organizational Innovation? An Empirical Evidence from Small and Medium-sized enterprises (SMEs). Pacific Business Review International, 12(1), 11-22.

[3] Alkamel, M. A. A., \& Chouthaiwale, S. S. (2018). The use of ICT tools in english language teaching and learning: a literature review. Journal of English Language and Literature (JOELL), 5(2), 29-33.

[4] Aydiner, A. S., Tatoglu, E., Bayraktar, E., Zaim, S., \& Delen, D. (2019). Business analytics and firm performance: The mediating role of business process performance. Journal of business research, 96, 228-237.

[5] Bigne, E., Chatzipanagiotou, K., \& Ruiz, C. (2020). Pictorial content, sequence of conflicting online reviews and consumer decision-making: The stimulus-organismresponse model revisited. Journal of Business Research.

[6] Chaffey, D., Hemphill, T., \& EdmundsonBird, D. (2019). Digital business and $e$ commerce management: Pearson UK.

[7] Chen, C.-C., \& Yao, J.-Y. (2018). What drives impulse buying behaviors in a mobile auction? The perspective of the StimulusOrganism-Response model. Telematics and Informatics, 35(5), 1249-1262.

[8] Chen, I.-J., \& Chang, C.-C. (2011). Content presentation modes in mobile language listening tasks: English proficiency as a moderator. Computer Assisted Language Learning, 24(5), 451-470.

[9] Chuang, S.-P., \& Huang, S.-J. (2018). The effect of environmental corporate social responsibility on environmental performance and business competitiveness: The mediation of green information technology capital. Journal of Business Ethics, 150(4), 991-1009.

[10] Coyle, J. R., \& Thorson, E. (2001). The effects of progressive levels of interactivity and vividness in web marketing sites. Journal of advertising, 30(3), 65-77.

[11] Fortin, D. R., \& Dholakia, R. R. (2005). Interactivity and vividness effects on social presence and involvement with a web-based advertisement. Journal of business research, 58(3), 387-396.

[12] Hameed, W. U., Basheer, M. F., Iqbal, J., Anwar, A., \& Ahmad, H. K. (2018). Determinants of Firm's open innovation performance and the role of $\mathrm{R} \& \mathrm{D}$ department: an empirical evidence from Malaysian SME's. Journal of Global Entrepreneurship Research, 8(1), 29.

[13] Hiranburana, K., Subphadoongchone, P., Tangkiengsirisin, S., Phoochaeoensil, S., Gainey, J., Thogsngsri, J., . . . Taylor, P. (2017). A Framework of Reference for English Language Education in Thailand (FRELE-TH)--Based on the CEFR, the Thai 
Experience. LEARN Journal: Language Education and Acquisition Research Network, 10(2), 90-119.

[14] Hubert, M., Blut, M., Brock, C., Backhaus, C., \& Eberhardt, T. (2017). Acceptance of smartphone-based mobile shopping: Mobile benefits, customer characteristics, perceived risks, and the impact of application context. Psychology \& Marketing, 34(2), 175-194.

[15] Kale, E., Aknar, A., \& Başar, Ö. (2019). Absorptive capacity and firm performance: The mediating role of strategic agility. International Journal of Hospitality Management, 78, 276-283.

[16] Kamboj, S., Sarmah, B., Gupta, S., \& Dwivedi, Y. (2018). Examining branding cocreation in brand communities on social media: Applying the paradigm of StimulusOrganism-Response. International Journal of Information Management, 39, 169-185.

[17] Kim, M. J., Lee, C.-K., \& Jung, T. (2020). Exploring consumer behavior in virtual reality tourism using an extended stimulusorganism-response model. Journal of Travel Research, 59(1), 69-89.

[18] Lee, Y.-J., Ghasemkhani, H., Xie, K., \& Tan, Y. (2019). Switching Decision, Timing, and App Performance: An Empirical Analysis of Mobile App Developers' Switching Behavior Between Monetarization Strategies. Timing, and App Performance: An Empirical Analysis of Mobile App Developers' Switching Behavior Between Monetarization Strategies (March 3, 2019).

[19] Malik, A., Merunka, D., Akram, M. S., Barnes, B. R., \& Chen, A. (2020). Selfconcept, individual characteristics, and counterfeit consumption: Evidence from an emerging market. Psychology \& Marketing.

[20] Muntinga, D. G., Moorman, M., \& Smit, E. G. (2011). Introducing COBRAs: Exploring motivations for brand-related social media use. International Journal of advertising, 30(1), 13-46.
[21] Nawaz, M. Z., Tao, M., Ahmad, H., Haque, M. J., Nawaz, S., \& Shafique, M. N. (2020). Youngsters and WMAs (WeChat Moments Advertisement): Do We Need the English Language in WMAs? SAGE Open, 10(2), 2158244020922840.

[22] Ntarlas, G., \& Karayanni, D. A. (2020). Exploring the Mediating Role of Interactivity Between Content Engagement and Business Performance in a Mobile-Marketing Strategy: A Quantitative Research in a Business-toBusiness Context Strategic Innovative Marketing and Tourism (pp. 815-823): Springer.

[23] Owan, V. J., \& Agunwa, J. N. (2019). Principals' Administrative Competence and Teachers' Work Performance in Secondary Schools in Calabar Education Zone of Cross River State, Nigeria. Online Submission, 7(1), 20-28.

doi:

10.18488/journal.73.2019.71.20.28

[24] Pennycook, A. (2020). Translingual entanglements of English. World Englishes, 39(2), 222-235.

[25] Popoola, O. T. (2019). Financial Inclusion and Health Shocks: A Panel Data Analysis of 36 African Countries. Asian Journal of Economics and Empirical Research, 6(1), 4551. doi: https://doi.org/10.20448/journal.501.2019.61. 45.51

[26] Puteri, L. H. (2018). The apperception approach for stimulating student learning motivation. International Journal of Education, Training and Learning, 2(1), 712.

doi: https://doi.org/10.33094/6.2017.2018.21.7.12

[27] Rahman, F., \& Amir, P. (2019). Trends in Reading Literary Fiction in Print and Cyber Media by Undergraduate Students of Hasanuddin University. International Journal of Education and Practice, 7(2), 66-77. doi: 10.18488/journal.61.2019.72.66.77 
[28] Rahmat, N. H. (2020). Writers' Block for Writers: How Far is it True? Studies, 6(1), 51-63. doi: 10.20448/807.6.1.51.63

[29] Rajapathirana, R. J., \& Hui, Y. (2018). Relationship between innovation capability, innovation type, and firm performance. Journal of Innovation \& Knowledge, 3(1), 44-55.

[30] Ramli, Y., \& Maysari, D. P. (2020). The Influence of Customer Attitude towards Customer Purchase Decision by Implementing Green Marketing. International Journal of Emerging Trends in Social Sciences, 8(2), 42-50. doi: https://doi.org/https://doi.org/10.20448/2001. 82.42 .50

[31] Riyanti, M. T. (2018). Development of learning devices commercial graphic based planning project. International Journal of Education, Training and Learning, 2(1), 1-6. doi:

https://doi.org/10.33094/6.2017.2018.21.1.6

[32] Sayed, M. N., \& Shusha, A. (2019). Determinants of Financial Inclusion in Egypt. Asian Economic and Financial Review, 9(12), 1383-1404. doi: 10.18488/journal.aefr.2019.912.1383.1404

[33] Seddighi, H., \& Yoon, I.-H. (2019). Demand for imports and components of final expenditure: An empirical study with special reference to the Korean import demand function. Asian Journal of Economics and Empirical Research, 6(1), 52-58. doi: https://doi.org/10.20448/journal.501.2019.61. 52.58

[34] Szymczak, A. (2018). The Use of Mobile Applications by Airlines in the Process of Marketing Communication. Marketing of Scientific and Research Organizations, 29(3), 133-153.

[35] Thongsri, N., \& Bao, Y. (2019). What Motivates Learners' Intention to Use Blackboard Mobile Learning (BML)?: Evidence from Thailand. Paper presented at the 2019 Twelfth International Conference on Ubi-Media Computing (Ubi-Media).

[36] Thongsri, N., Shen, L., \& Bao, Y. (2019). Investigating factors affecting learner's perception toward online learning: evidence from ClassStart application in Thailand. Behaviour \& Information Technology, 38(12), 1243-1258.

[37] Ul-Hameed, W., Mohammad, H., \& Shahar, H. (2018). Microfinance institute's nonfinancial services and women-empowerment: The role of vulnerability. Management Science Letters, 8(10), 1103-1116.

[38] V Butova, A., I Dubskikh, A., Kisel, O. V., \& G Chigintseva, E. (2019). Electronic educational environment Moodle in English language training. Arab World English Journal (AWEJ) Volume, 10.

[39] van der Worp, K., Cenoz, J., \& Gorter, D. (2018). 9 Language policy in business and industry: Between local and global developments Un (intended) Language Planning in a Globalising World: Multiple Levels of Players at Work (pp. 145-162): Sciendo Migration.

[40] Verma, P. (2020). The effect of presentation, product availability and ease upon transaction reliability for online food delivery aggregator applications-moderated mediated model. Journal of Foodservice Business Research, 120.

[41] Wichadee, S., \& Pattanapichet, F. (2018). Enhancement of performance and motivation through application of digital games in an English language class. Teaching English with Technology, 18(1), 77-92.

[42] Wongwuttiwat, J., Buraphadeja, V., \& Tantontrakul, T. (2020). A case study of blended e-learning in Thailand. Interactive Technology and Smart Education.

[43] Yang, H.-S., \& Park, J.-W. (2019). A study of the acceptance and resistance of airline mobile application services: with an emphasis on user characteristics. International Journal of Mobile Communications, 17(1), 24-43. 
[44] Yi, J., He, J., \& Yang, L. (2019). Platform heterogeneity, platform governance and complementors' product performance: an empirical study of the mobile application industry. Frontiers of Business Research in China, 13(1), 13.

[45] Zhang, N., Pang, J., \& Wan, J. (2018). Selfdisclosure in Social Network Sites: An Integration of Stimulus-Organism-Response Paradigm and Privacy Calculus Model. Paper presented at the WHICEB.

[46] Zhao, Y., Wang, A., \& Sun, Y. (2020). Technological environment, virtual experience, and MOOC continuance: A stimulus-organism-response perspective. Computers \& Education, 144, 103721. 